\title{
Analysis of the microclimatic behavior of a greenhouse used to produce carnation (Dianthus caryophyllus L.)
}

\author{
Edwin Villagran ${ }^{1 *}$, Carlos Bojacá2
}

\begin{abstract}
Carnation production in Colombia, the world's main exporter, takes place entirely in naturally ventilated greenhouses. This type of structure presents non-homogeneous microclimate conditions which differentially affect crop growth and development, which is why this issue has been of great research interest in recent years. The objective was to determine the microclimatic behavior of a passive spatial-type greenhouse used in Colombia for carnation production. The experimental approach included the collection of meteorological data in the external environment through a weather station and in the inside of the greenhouse through a grid of 40 sensors uniformly distributed in a horizontal plane. Data processing to determine the spatial variability of temperature, relative humidity and vapour pressure deficit (VPD) is done by using geostatistical techniques and predicting these variables at unsampled points through the ordinary Kriging method. The main results obtained allowed us to determine that the conditions generated inside the greenhouse are not the optimal ones recommended for carnation production and that, in addition, the behavior of the variables studied shows a heterogeneous distribution, obtaining spatial variations in the horizontal profile evaluated for the night period of $0.5{ }^{\circ} \mathrm{C}, 9.1 \%$ and $1.5 \mathrm{kPa}$ and for the daytime period of $7.2{ }^{\circ} \mathrm{C}, 42.6 \%$ and $1.5 \mathrm{kPa}$ for temperature, humidity and VPD respectively. Keywords: climatic heterogeneity, prediction, Kriging, temperature, humidity.
\end{abstract}

\section{Resumo}

Análises do desempenho microclimático de uma estufa utilizada para produção de cravo (Dianthus caryophyllus L.) A produção de cravos na Colômbia, o principal exportador mundial, é realizada inteiramente em estufas agrícolas com ventilação natural. Neste tipo de estrutura, estão presentes condições microclimáticas não homogêneas, que afetam negativamente o crescimento e desenvolvimento dos cultivos, razão pela qual esta questão tem sido de grande interesse de pesquisa nos últimos anos. O objetivo foi determinar o desempenho microclimático de estufa agrícola com ventilação natural de tipo espacial utilizada na Colômbia para a produção de cravo. A abordagem experimental incluiu a coleta de dados meteorológicos no ambiente externo através de uma estação meteorológica e no interior da estufa através de uma grade de 40 sensores uniformemente distribuídos em um plano horizontal. O processamento de dados para determinar a variabilidade espacial da temperatura, umidade relativa e déficit de pressão de vapor (VPD) foi feito usando técnicas geoestatísticas e prevendo estas variáveis em pontos não amostrados através do método de Kriging comum. Os principais resultados obtidos permitiram determinar que as condições geradas dentro da estufa não são as ideais recomendadas para a produção de cravos e que, além disso, o desempenho das variáveis estudadas mostra uma distribuição heterogênea, obtendo variações espaciais no perfil horizontal avaliado para o período noturno de $0,5^{\circ} \mathrm{C}, 9,1 \% \mathrm{e} 1,5 \mathrm{kPa}$ e para o período diurno de $7,2{ }^{\circ} \mathrm{C}, 42,6 \%$ e $1,5 \mathrm{kPa}$ para a temperatura, umidade e VPD, respectivamente.

Palavras-chave: heterogeneidade climática, previsão, Kriging, temperatura, umidade.

\section{Introduction}

One of the most relevant activities in the agricultural sector is floriculture, this can be defined as the branch of ornamental horticulture that is dedicated to the development and production of ornamentals and cut flowers (Adeola et al., 2018; Nassar and Ribeiro, 2019; Paiva, 2018). In Colombia the ornamental sector and its distribution chain contributes $7 \%$ of the agricultural national gross domestic product and is one of the industries that drives economic development and at the same time one of the industries that generates the highest level of employment (Rodríguez and

\footnotetext{
${ }^{1}$ Universidad Jorge Tadeo Lozano, Facultad de Ciencias Naturales e Ingeniería, Departamento de Ciencias Biológicas y Ambientales, Bogotá, Colombia. "Corresponding autor: edwina.villagranm@utadeo.edu.co

${ }^{2}$ Universidad Jorge Tadeo Lozano, Facultad de Ciencias Naturales e Ingeniería, Departamento de Ciencias Básicas y Modelado, Bogotá, Colombia.
}

Received Fev 20, 2020| Accepted Apr 20, 2020| Available online May 7, 2020

Licensed by CC BY 4.0

https://doi.org/10.1590/2447-536X.v26i2.2150

Area Editor: Gilmar Schafer 
Junco, 2016). The same has happened in other regions such as; Brazil, Ecuador, India, Kenya and Thailand (Junqueira and Peetz, 2018; Knapp, 2017; Newman, 2019).

The carnation (Dianthus caryophyllus L.) is a perennial herbaceous plant member of the dicotyledonous family Caryophyllaceae, this family of plants has approximately 2,200 species, while the genus Dianthus includes about 300 species that grow in different countries of the world (Al-Ma'athedi et al., 2018; Boxriker et al., 2017b; Yagi et al., 2020). The carnation is one of the most important cut flowers globally, ranking third in the ornamental market after the rose and chrysanthemum (Abeliotis et al., 2016; Boxriker et al., 2017a; Liu et al., 2018). The main commercial characteristics of the carnation are; the shape, size and colour of the flowers, the fragrance, its long vase life of over 14 days and its ability to withstand transport over long distances (Abeliotis et al., 2016; Ahmadian et al., 2017; Al-Ma'athedi et al., 2018; Boxriker et al., 2017a; Onozaki, 2018; Singh et al., 2016).

In the Colombian ornamental sector, passive greenhouses with natural ventilation predominate, the 4 characteristic models are; the traditional Colombian, the multi-tunnel type, the hanging type and finally the spatial type (Villagrán-Munar and Bojacá-Aldana, 2019; Villagrán Munar et al., 2018). The use of these cover structures seeks to generate adequate microclimate conditions in order to guarantee the supply of high quality commercial products throughout the months of the year and at the same time increase the yields and productivity of the crops (Ma et al., 2019b; Neira et al., 2018). One of the main problems of these greenhouses is their limited ventilation capacity and their large size, therefore it is characteristic to find heterogeneous spatial distributions of temperature and relative humidity (Villagrán et al., 2019; Villagrán and Bojacá, 2019a).

The study of microclimate distribution in greenhouse structures in recent years is mainly addressed through CFD simulation approaches and from dynamic mass and energy balance models (López-Cruz et al., 2018). We seek to determine the spatial distribution of temperature and relative humidity, since they are variables that have a direct relationship in physiological and biological processes of plants, therefore any heterogeneous spatial distribution will affect in a differentiated way the uniformity of growth and development of crops and in turn the quality of the final product obtained (Ma et al., 2019 a,b; Saberian and Sajadiye, 2019). Other experimental studies not focused on carnations have reported temperature and humidity gradients in both the vertical and horizontal profiles of the evaluated greenhouses (Balendonck et al., 2014; Bojacá et al., 2009a; Diano et al., 2016; Fatnassi et al., 2015; Ferentinos et al., 2017; García-Ruiz et al., 2018). The main objective of this research was to carry out the characterization through geostatistical techniques of the temperature and humidity behavior inside a commercial greenhouse of the space type used for carnation production in the savannah of Bogota Colombia.

\section{Materials and Methods}

\section{Greenhouse description and information collection}

The collection of experimental information was carried out in a municipality producing cut flowers located in the surroundings of the savannah of Bogota Colombia, the type of greenhouse evaluated was one of the so-called spatial type, its covered area was 17,892 $\mathrm{m}^{2}$ fully established in carnation cultivation. This greenhouse structure is manufactured by embedding pillars built in concrete and forming a flat cover in structural steel cables where the polyethylene is attached (Figure 1B). The greenhouse was made up of 42 attached spans, each $7.1 \mathrm{~m}$ wide (Figure 1A). The minimum and maximum heights under the gutter were 3.5 and $5.5 \mathrm{~m}$ respectively, the longitudinal distance of the greenhouse was $60 \mathrm{~m}$ and it was oriented in a NorthSouth direction. Each span had a fixed roof ventilation area with an opening of $0.25 \mathrm{~m}$ (Figure 1C) which is equivalent to a roof ventilation area of $615 \mathrm{~m}^{2}$, representing $3.43 \%$ in reference to the floor area covered. In addition, the ventilation areas were complemented on all four sides of the greenhouse with a $2.2 \mathrm{~m}$ opening, making up a side ventilation area of $1,554 \mathrm{~m}^{2}$, which represents $8.68 \%$ of the covered floor area. 
A)

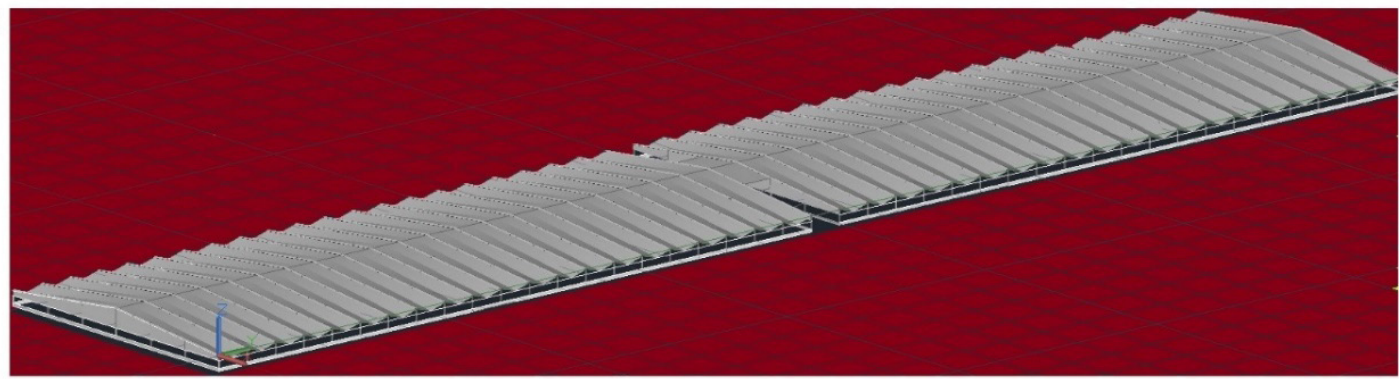

B)

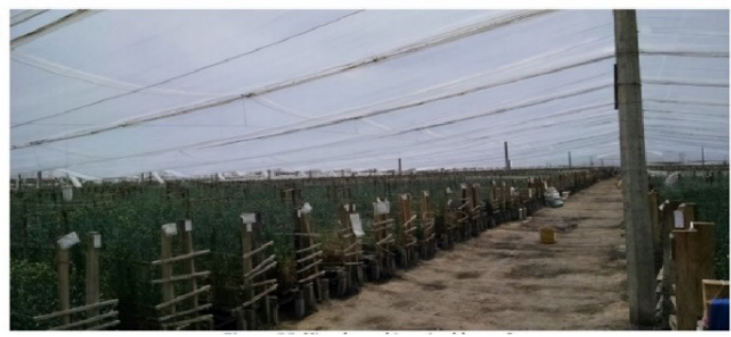

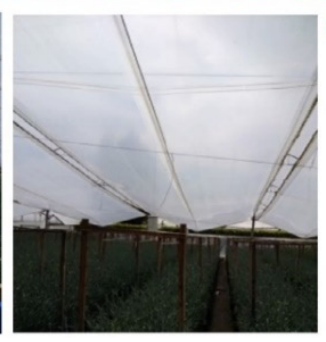

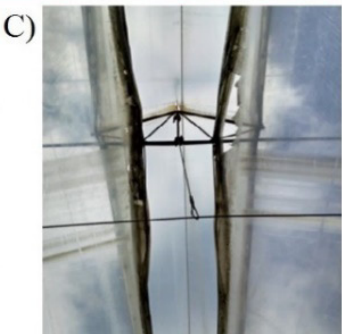

Figure 1. A) General scheme of the space greenhouse,

B) Details of the interior of the greenhouse and C) Ventilation area

Weather conditions outside the greenhouse such as air temperature and humidity, solar radiation, wind speed and direction were recorded and stored by means of an automatic weather station i-Metos Compact station (Pessl Instruments $\mathrm{GmbH}$, Weiz, Austria). Inside the greenhouse 40 type-T copper thermocouples used to measure dry bulb and wet bulb temperatures were distributed and stored in a data logger (Cox-Tracer Junior, Escort DLS, Edison, NJ, EE. UU.). The thermocouples were arranged in a ventilated capsule that acted as a shield from direct solar radiation. The data collection points inside the greenhouse were distributed in a regular grid in the horizontal direction at a height of $1.6 \mathrm{~m}$ above the ground and with a cell size of $12 \times 37.2 \mathrm{~m}$, which gives a sampling point every $446.4 \mathrm{~m}^{2}$. Both outside and inside, the frequency of measurement and data recording was 15 minutes during the period from 12 July to 16 August 2018.

\section{Geostatistical analysis}

An analysis using geostatistical techniques generally consists of three main stages: exploratory analysis of the data, analysis of the spatial relationship or structural analysis and finally the estimation or simulation of data better known as prediction. For the measurement period, depending on the intensity levels of the external solar radiation, the data obtained was grouped into 5 levels (W $\mathrm{m}^{-2}$ ), including the night which corresponds to group 1 of 0 $\mathrm{W} \mathrm{m} \mathrm{m}^{-2}$. Each hourly average data set was then grouped into one of the 5 radiation levels and the geostatistical analysis was applied as described below.

\section{Exploratory analysis}

This analysis is generally performed in order to fulfill several purposes, among the most important: to verify some geostatistical assumptions such as stationarity and periodicity. In this phase of the process, graphics are usually used to allow inspection of the stationarity of the variable (Isaaks et al.,1989). It is also of interest to verify if the data are stationary, that is, if they present a periodic behavior. For this, it is assumed that the degree of association of these data is a function of the spatial separation and not of the location of these data in space. Additionally, basic statistics are used, in this case the Shapiro-Wilk test, to determine the statistical distribution of the data and to verify that they comply with the assumption of normality. Additionally, for the calculation and subsequent analysis of the distribution of relative humidity $(\mathrm{RH})$ and the vapour pressure deficit (VDP), the following psychrometric relations were used Huang et al. (2013).

\section{Structural analysis}

In this stage we seek to determine a spatial dependence function that is valid for the empirical semivariate, the graphic relationship between the spatial separation distances and the semivariate of the variable studied is known as the semivariogram (Bojacá et al., 2009b). In this phase the isotropic experimental semivariograms were constructed for each of the data sets obtained from each variable inside the greenhouse. The empirical semivariograms are constructed using the following equation.

$$
\gamma(h)=\frac{1}{2 N p(h)} \sum_{i=1}^{N p(h)}[Z(x i)-Z(x i+h)]^{2}
$$

Where: $N_{p(h)}$ is the number of pairs at a distance $\mathrm{h}, \mathrm{h}$ is the increase, $\mathrm{Z}$ (xi) are the experimental values and are the experimental values and $x i$ the locations where the values are measured $\mathrm{Z}(\mathrm{xi})$. 
The shape of the empirical omnidirectional semivariogram can be adjusted to a variety of theoretical semiviogram models. For the analysis of these data sets, the performance of the following models was evaluated: circular, exponential, spherical and Gaussian. The basic parameters of this type of models are range $(a)$, sill $\left(\mathrm{c}_{1}\right) \mathrm{y}$ nugget $\left(\mathrm{c}_{0}\right)$. The sill represents the upper asymptote of the semivariogram and corresponds to the maximum variability explained by the semivariogram, the range represents a measure of the maximum influence distance and the nugget represents both the sampling error and the spatial variability for the minimum distance interval (Bojacá et al., 2009b). The selection of the semivariogram model that will be used to make the prediction was made through the analysis of the following criteria, Akaike's information criterion (AIC) and the Bayesian information criterion (BIC). The models that presented the lowest values for these two adjustment criteria were selected as the theoretical semivariogram model that best represents the data set evaluated inside the greenhouse.

\section{Prediction}

In this phase we seek to predict the variables of interest in unsampled points from known values and their spatial continuity structure. The predominant estimation method is kriging by the ordinary method, which is considered as an optimal, unbiased and minimum variance linear predictor where the prediction is given by the following equation:

$$
\mathrm{Z}\left(\mathrm{x}_{0}\right)=\sum_{\mathrm{i}=1}^{\mathrm{n}} \lambda_{\mathrm{i}} \mathrm{Z}\left(\mathrm{x}_{\mathrm{i}}\right) \quad \text { con } \quad \sum_{\mathrm{i}=1}^{\mathrm{n}} \lambda_{\mathrm{i}}=1
$$

Where: are the weights that are assigned to each value of the variable in the observed positions $Z\left(x_{0}\right)$ based on the parameters of the previously adjusted theoretical semivariogram (Cressie, 1992).

Once this procedure has been carried out, maps are drawn up showing the representation of the variable of interest, where the main types of maps used are contour distribution maps.

\section{Results and Discussion}

\section{Exploratory analysis}

From the experimental information collected, the data of the three variables under study were grouped according to solar radiation. In this way, for the external solar radiation recorded during the measurement period, the quartiles were calculated excluding the solar radiation recorded during the nighttime as it is equal to zero, in total the data were grouped in 5 radiation levels (Table 1). These are upper limits of the radiation level at which the data of the climate variables under study were grouped for subsequent analysis using geostatistical methods.

Table 1. Upper limit of the global solar radiation levels $\left(\mathrm{W} \mathrm{m}^{-2}\right)$ at which the data were grouped for geostatistical analysis.

\begin{tabular}{|c|c|c|c|c|c|}
\hline & Group 1 & Group 2 & Group 3 & Group 4 & Group 5 \\
\hline $\begin{array}{c}\text { Radiation level } \\
\left(\mathbf{W m}^{-\mathbf{2}} \mathbf{n}\right.\end{array}$ & 0 & 91.80 & 274.17 & 486.29 & 968.83 \\
\hline
\end{tabular}

This exploratory analysis was performed for a total of 15 experimental data sets corresponding to a sensor grid located at a height of $1.6 \mathrm{~m}$, for 5 data sets (Table 1) of three variables (Temperature, Relative Humidity and Vapor Pressure Deficit). Next, the results obtained in the exploratory analysis will be presented explaining what was found for a specific radiation group both for temperature, relative humidity and vapour pressure deficit, the results obtained for the other groups were like those presented in this paper.

\section{Temperature, relative humidity and VPD}

The average temperature for the 24-hour sensor grid installed in the greenhouse was $16.1{ }^{\circ} \mathrm{C}$ during the measurement period, which is $1.9{ }^{\circ} \mathrm{C}$ higher than the average temperature of the outside environment (Figure
2A). When separating the behavior during the day and the night, it is observed that for the night period the behavior of the temperature inside the greenhouse was similar to that of the temperature outside, obtaining values of 12.2 and $12.3{ }^{\circ} \mathrm{C}$ respectively, it should be noted that for this period inside the greenhouse, in most hours, the phenomenon of thermal inversion occurs, with which the temperature of the air inside the greenhouse is lower than that of the air in the outside environment, a situation that is not convenient for agricultural production, this phenomenon of thermal inversion is caused by the low capacity of polyethylene to retain long wave thermal radiation, which is in accordance with what is reported by (Villagran and Bojaca, 2019d). On the other hand, for the day period the average temperature value indoors was $19.9^{\circ} \mathrm{C}$ while outdoors it was $16.1^{\circ} \mathrm{C}$ (Figure 2A). 

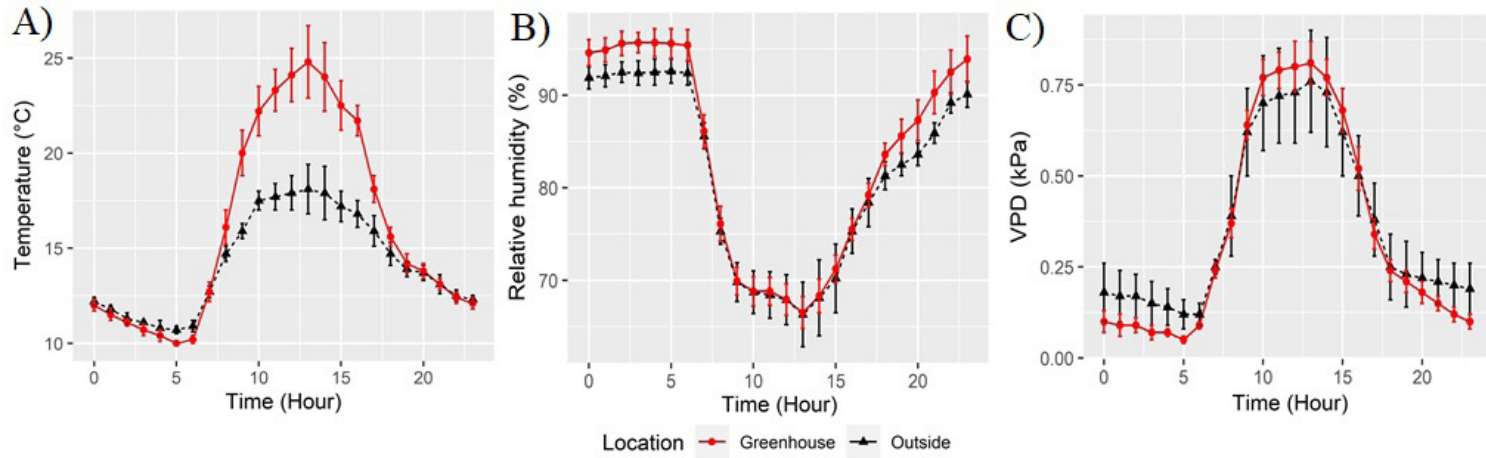

Figure 2. Time behavior of variables evaluated in the inside and outside environment of the greenhouse, A) Temperature $\left.\left({ }^{\circ} \mathrm{C}\right), \mathrm{B}\right)$ Relative humidity (\%) and C) VPD $(\mathrm{kPa})$.

In principle it can be mentioned that the temperatures inside the greenhouse were within the recommended range for carnation cultivation, since for this crop we are looking for temperatures between 8 and $25^{\circ} \mathrm{C}$, a range in which the formation of flower buds is induced (Márquez, 2000). However, studies conducted in Colombia by Boshell. (2009) it is recommended that the daytime temperature does not exceed $22{ }^{\circ} \mathrm{C}$ as in this study between 10 and 15 hours, these high temperature values generate a more accelerated vegetative cycle with a consequent loss of quality in the final product, generating shorter stems and smaller flowers, with a shorter vase life. Also in accordance with the proposal of Newman (1999) for the hours 6 and 7 the greenhouse temperature is below the minimum recommended value for the day period which should be 15 ${ }^{\circ} \mathrm{C}$ and that according to the author under these conditions the formation of flattened flowers with partial opening is promoted.

The average relative humidity behavior in the indoor and outdoor environment of the greenhouse was $82.3 \%$ and $81.3 \%$ for 24 hours a day during the measurement period (Figure $2 \mathrm{~B}$ ). The average values of relative humidity obtained for the hours of the daytime period in the internal and external environment of the greenhouse were $74.5 \%$ and $73.8 \%$ respectively, while for the nighttime hours values of $88.8 \%$ and $92.1 \%$ were obtained, in general the highest average values of relative humidity in the inside of the greenhouse are due to the contribution of humidity via transfer of mass by phenomena of transpiration in the crop and of evaporation of water from the soil. For this variable the behavior presented inside the greenhouse is inadequate mainly for the night period and for the hours of the day with the exception of the period between 10 and 14 hours, for carnation cultivation it is advisable to have an environment with humidity between $65 \%$ and $70 \%$. Behavior with higher relative humidity values can generate a favorable environment for the development of fungal diseases and the proliferation of pests such as Thrips, in addition this type of environment is harmful to the plant because the stems become susceptible to damage by bending or fracture when in high turgidity condition (Correll and Weathers, 2001; Fatnassi et al., 2015).

In the case of the DPV, the behavior of the average value for 24 hours a day in the external and internal environment of the greenhouse showed values of 0.36 and $0.34 \mathrm{kPa}$ respectively (Figure 2C). The behavior for the day period presented values of 0.54 and $0.56 \mathrm{kPa}$, while for the night hours it was 0.18 and $0.12 \mathrm{kPa}$ for the external and internal environment of the greenhouse respectively. The values of VPD are directly related to the behavior of both temperature and relative humidity. For this reason, this variable is considered an integral parameter that serves to make decisions in the climate management of greenhouses such as; activation of heating, cooling and handling opening and closing of ventilation areas (González et al., 2019; Rabbi et al., 2019). In general it can be seen that the average values for the hours of the day are very close to the recommended minimum value of $0.4 \mathrm{kPa}$ and are far below the optimum value of $0.85 \mathrm{kPa}$ necessary to ensure good biological and physiological functioning of the plants and to limit the development of pests and diseases as much as possible. On the other hand, for the night period the value obtained is inadequate since values lower than $0.2 \mathrm{kPa}$ facilitate the development of fungal diseases (Konopacki et al., 2018).

The last stage of the exploratory analysis included the construction and checking of scatter plots as a function of spatial coordinates for data obtained from; temperature, relative humidity and VPD of the data sets grouped by radiation level (Figures 3A-C). In these figures there is no considerable trend in the width and length of the greenhouse. Likewise, the histogram of the data grouped for three levels of radiation (Figure 3) can be observed. In principle, it can be inferred that, due to the bell shape of the histograms, there is an adjustment to the normality of the data sets, additionally, to confirm the assumption of normality, the Shapiro-Wilk test was performed, where it is established that the $p$ value must be greater than the defined alpha (0.05), obtaining a $p$ value of $0.4809,0.3906$ and 0.3314 for temperature, relative humidity and VPD which validates the assumption of normality for this data set. 

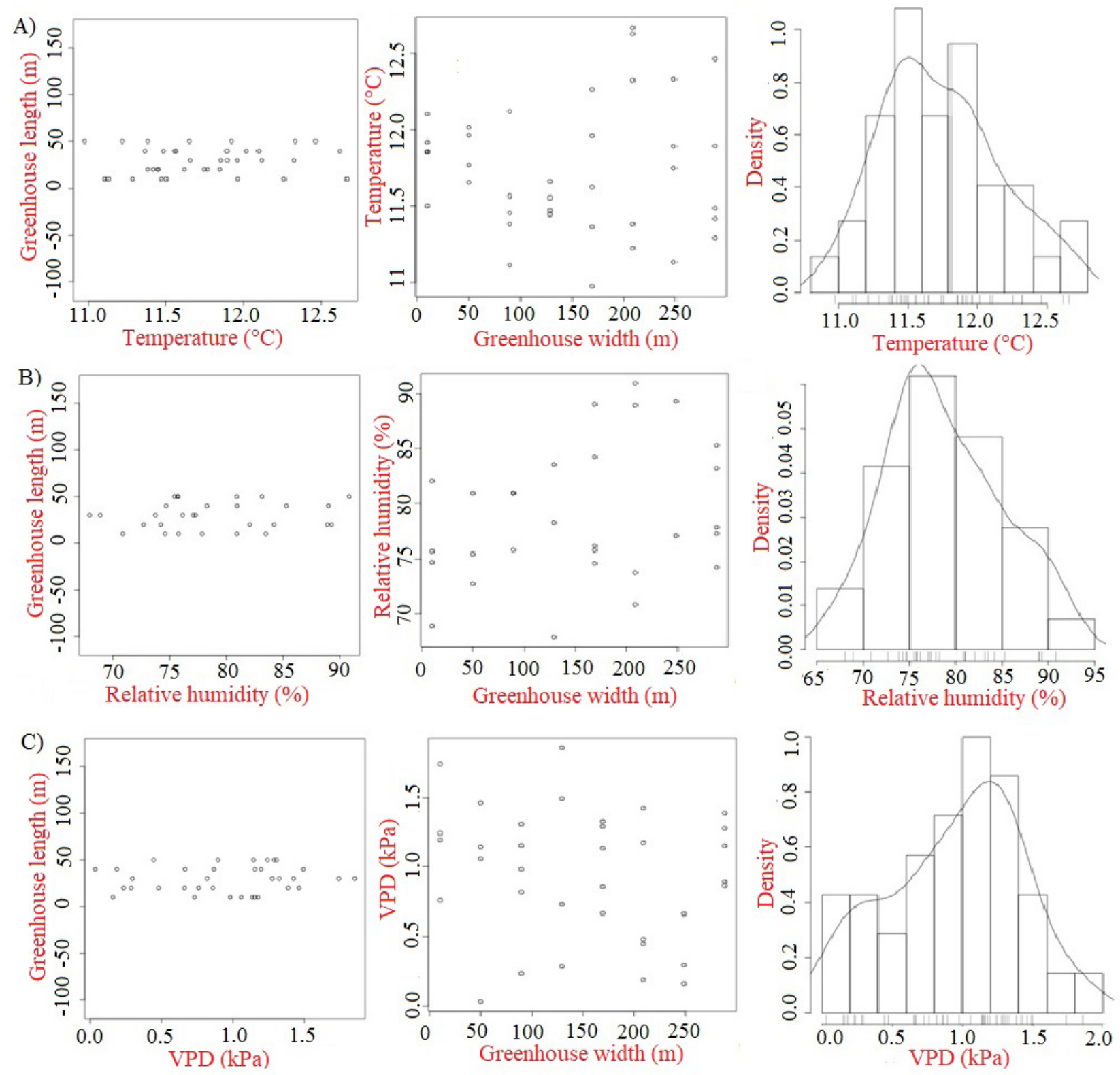

Figure 3. A) Results of exploratory spatial analysis, A) Temperatures of radiation group $1\left(0 \mathrm{Wm}^{-2}\right)$, B) Relative humidity of radiation group $3\left[91.80-274.17 \mathrm{~W} \mathrm{~m}^{-2}\right.$ ) and C) VPD of radiation group 5 [468.30-968.83 $\mathrm{W} \mathrm{m}^{-2}$ ).

\section{Structural analysis}

\section{Temperature}

The results obtained for this phase of the geostatistical analysis indicated that as the radiation levels increase, the semi-variance values are greater, which will translate into a behavior with greater variation in temperature at a spatial level inside the greenhouse, likewise, the semivariograms obtained for the night hours and at low levels of radiation such as those that occur at dawn or dusk of the day showed a smaller range of variation in the internal temperature of the greenhouse, these results coincide with those obtained in the study developed by Bojacá et al. (2009a). Of the theoretical semivariogram models used to fit the data of the empirical semivariograms, it was established that the circular model best represented the observed values for the total of the radiation level groups into which the data were divided, this was determined through the AIC and BIC parameters (Table 2). 
Table 2. Parameters of the theoretical semivariogram model selected for the temperature datasets of the evaluated greenhouse.

\begin{tabular}{|c|c|c|c|c|c|c|c|}
\hline Group & Model & Nugget $\left(c_{0}\right)$ & Sill $\quad\left(c_{1}\right)$ & $\begin{array}{c}\left(c_{o l} c_{l)}\right. \\
(\%)\end{array}$ & Range $(a, \mathrm{~m})$ & AIC & BIC \\
\hline 1 & Circular & 0.02 & 0.16 & 15.38 & 9.83 & 125.11 & 54.97 \\
\hline 2 & Circular & 0.10 & 0.90 & 11.11 & 19.48 & 48.42 & 52.28 \\
\hline 3 & Circular & 0.00 & 0.52 & 0.00 & 20.40 & 94.71 & 88.31 \\
\hline 4 & Circular & 0.00 & 1.70 & 0.00 & 20.76 & 99.45 & 135.03 \\
\hline 5 & Circular & 0.00 & 3.10 & 0.00 & 20.65 & 147.73 & 154.18 \\
\hline
\end{tabular}

The values of the parameter $c_{0}$ for the radiation levels from 3 to 5 were equal to zero while for the other groups values between 0.02 and 0.1 were obtained, these values of nugget effect with low magnitude indicate that only a small part of the spatial dependence is due to an experimental error. The behavior of the parameter sill $\left(c_{1}\right)$ ranges from 0.16 to 3.1 , this shows that there is a greater spatial variation in temperature as the level of radiation increases, the value of $\mathrm{c} 1$ showed an increasing behavior depending on the level of radiation assessed. The range values $(a)$ were found between 9.83 and 20.76 $\mathrm{m}$, where particularly two groups are differentiated. The results of the relationship $c_{0} c_{1}$ with values below $25 \%$ indicate a strong spatial dependence (Cambardella et al., 1994).

\section{Relative Humidity}

For this case the circular model was the theoretical semivariogram model that indicated the best degree of fit for the experimentally observed data (Table 3 ). The values of $c_{0}$ ranged from 0 to 6.99 . The values for parameter $\mathrm{c} 1$ show a clear incremental trend as radiation levels increase, a higher value of $c_{1}$ will result in a greater spatial variation of the variable, this parameter varies between 14.10 and 84.34. The results between 0 and $21 \%$ of the ratio $c_{0} c_{1}$ show that there is a strongly structured spatial dependence.

Table 3. Parameters of the theoretical semi-variogram model selected for the relative humidity data sets located in the evaluated greenhouse

\begin{tabular}{|c|l|c|c|c|c|c|c|}
\hline Group & Model & Nugget $\left(\boldsymbol{c}_{\boldsymbol{0}}\right)$ & Sill $\left(\boldsymbol{c}_{\boldsymbol{l}}\right)$ & $\begin{array}{c}\left(\boldsymbol{c}_{\boldsymbol{g}} \boldsymbol{c}_{\boldsymbol{l}}\right. \\
\mathbf{( \% )}\end{array}$ & $\begin{array}{c}\text { Range } \\
(\boldsymbol{a} \mathbf{m})\end{array}$ & AIC & BIC \\
\hline $\mathbf{1}$ & Circular & 2.84 & 14.10 & 20.14 & 9.97 & 166.71 & 172.04 \\
\hline $\mathbf{2}$ & Circular & 2.57 & 22.52 & 11.41 & 9.99 & 163.46 & 168.79 \\
\hline $\mathbf{3}$ & Circular & 6.99 & 38.76 & 18.03 & 9.82 & 194.34 & 199.81 \\
\hline $\mathbf{4}$ & Circular & 5.45 & 58.71 & 9.28 & 9.99 & 210.79 & 216.26 \\
\hline $\mathbf{5}$ & Circular & 0.00 & 114.16 & 0.00 & 10.87 & 227.67 & 233.14 \\
\hline
\end{tabular}

\section{Vapour pressure deficit}

In the case of this variable it was also found that the circular model was the theoretical semivariogram model that fitted the experimental data (Table 4). The $a$ values ranged from 9.94 to $12.95 \mathrm{~m}$, and the $c_{0} c_{1}$ ratio values below $25 \%$ again indicate that there is spatial dependence. 
Table 4. Parameters of the theoretical semivariogram model selected for the evaluated greenhouse vapour pressure deficit data sets.

\begin{tabular}{|c|c|c|c|c|c|c|c|}
\hline Group & Model & Nugget $\left(c_{0}\right)$ & Sill $\quad\left(c_{1}\right)$ & $\begin{array}{c}\left(c_{0 /} c_{l)}\right. \\
(\%)\end{array}$ & $\begin{array}{l}\text { Range } \\
(a, \mathrm{~m})\end{array}$ & AIC & BIC \\
\hline 1 & Circular & 0.00 & 0.002 & 0.00 & 11.54 & -101.81 & -95.821 \\
\hline 2 & Circular & 0.00 & 0.005 & 0.00 & 9.94 & -70.794 & -64.85 \\
\hline 3 & Circular & 0.00 & 0.034 & 0.00 & 9.85 & -5.88 & 0.333 \\
\hline 4 & Circular & 0.005 & 0.11 & 4.54 & 10.96 & 27.02 & 33.24 \\
\hline 5 & Circular & 0.0 & 0.22 & 0.00 & 12.95 & 53.18 & 59.40 \\
\hline
\end{tabular}

\section{Prediction}

\section{Temperature}

The spatial temperature distribution for each of the data groupings by radiation level shows a non-homogeneous behavior of this variable (Figure 4). The average temperature values obtained were 11.8, 13.4, 18.3, 22.4 and $24.5{ }^{\circ} \mathrm{C}$ for the radiation groups 1 to 5 respectively.
The differential values between the coldest and hottest point inside the greenhouse varied significantly according to the increase in the radiation level except for the night period where a difference of $1.6{ }^{\circ} \mathrm{C}$ was found (Figure $4 \mathrm{~A})$. For the day period groups $2.3,4$ and 5 differentials of $0.5,3.1,6.1$ and $7.2{ }^{\circ} \mathrm{C}$ respectively were obtained (Figures 4B-E). 
A)

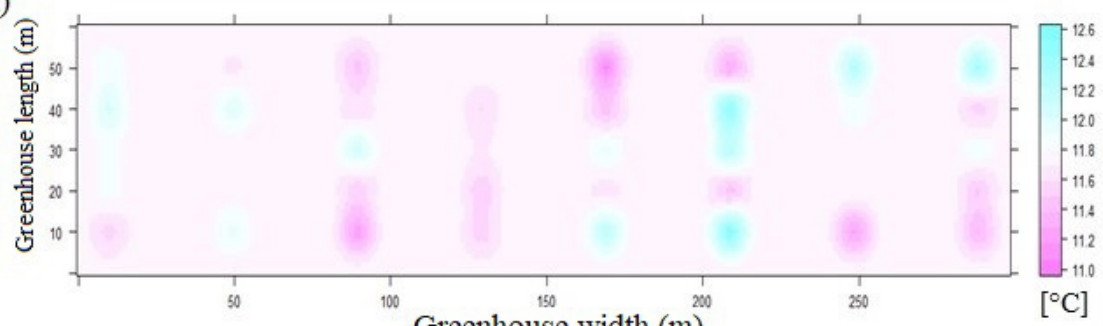

B)
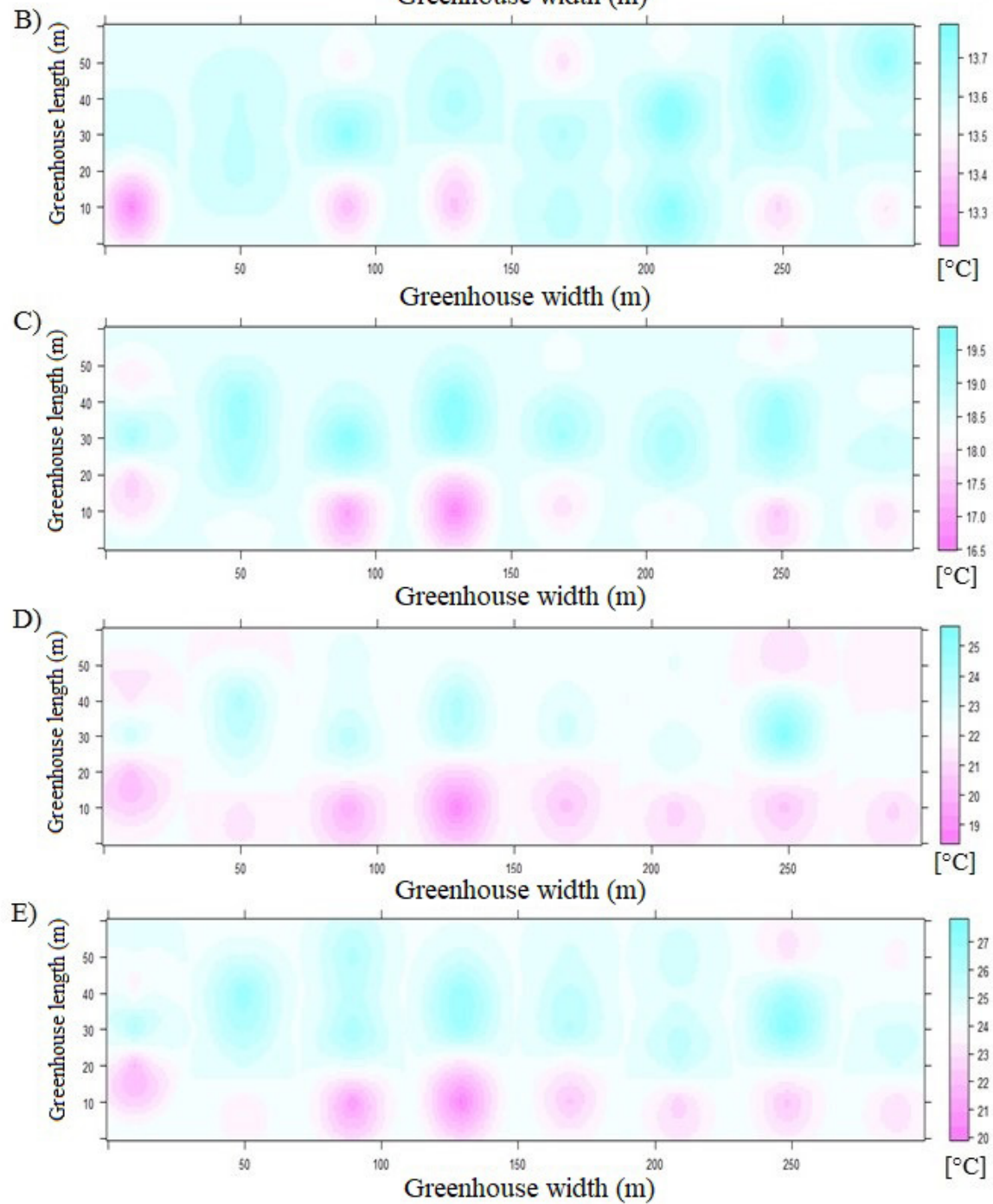

Figure 4. Spatial temperature prediction, A) group 1, B) group 2, C) group 3, D) group 4 and C) group 5.

The qualitative distribution allows us to observe that there are many circular patches that are generated from the greenhouse facades and move towards the central area. This non-homogeneous behavior of the temperature variable is not suitable for production under glass because it goes against one of the main objectives of agriculture under cover, which is to obtain uniform and high-quality production. The temperature differences in the horizontal plane are much greater than the recommended variation value for glasshouses, which is $\pm 2{ }^{\circ} \mathrm{C}$ (Zorzeto et al., 2014). This type of behavior in passive structures is due to inadequate greenhouse designs with low heights and lengths greater than 40 meters, in turn due to deficiencies in ventilation rates generated by areas of insufficient ventilation as is the case of the greenhouse under evaluation, where the ventilation surface area is well below the recommended value of $30 \%$ depending on the surface area covered (Baeza et al., 2009; Villagrán and Bojacá, 2019b).

\section{Relative Humidity}

The spatial distribution of the humidity is related to the temperature because the hot regions are drier and the colder ones more humid, therefore the humidity presented a heterogeneous behavior like the temperature (Figure 5). he average relative humidity values obtained for the radiation 
groups 1 to 5 showed average values of $94.1 \%, 91.1 \%$, $78.5 \%, 69.3 \%$ and $64.1 \%$ respectively, while the differentials between the points with the highest and lowest humidity contents showed values of $9.1 \%, 8.5 \%, 15.5 \%, 25.9 \%$ and
$42.6 \%$ (Figures 5A-E). For the case of humidity it can also be concluded that the behavior is quite heterogeneous the recommended limit of variation is $\pm 3 \%$ for humidity ranges between $70 \%$ and $80 \%$ (Zorzeto et al., 2014).

A)

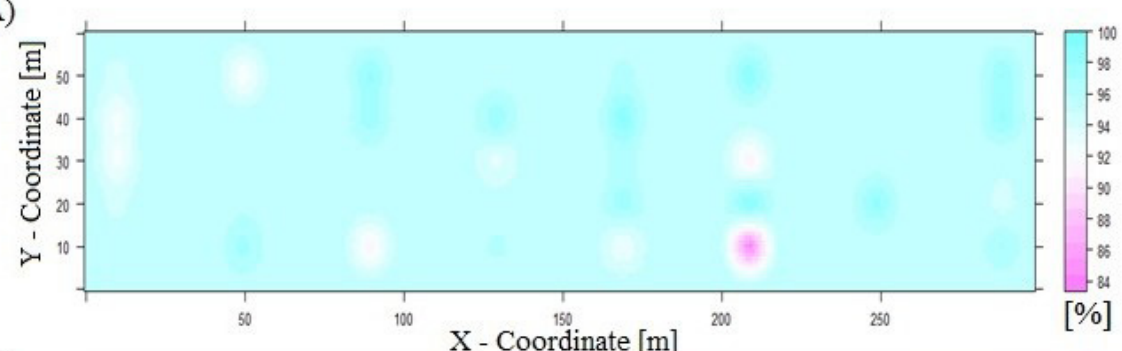

B)

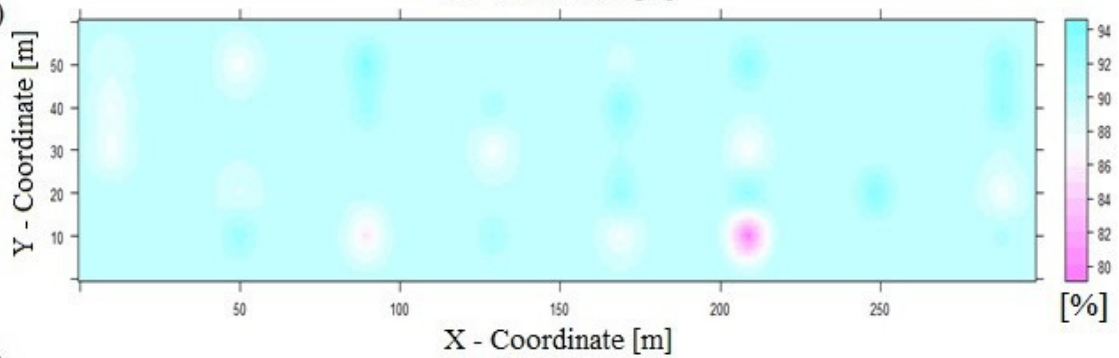

C)

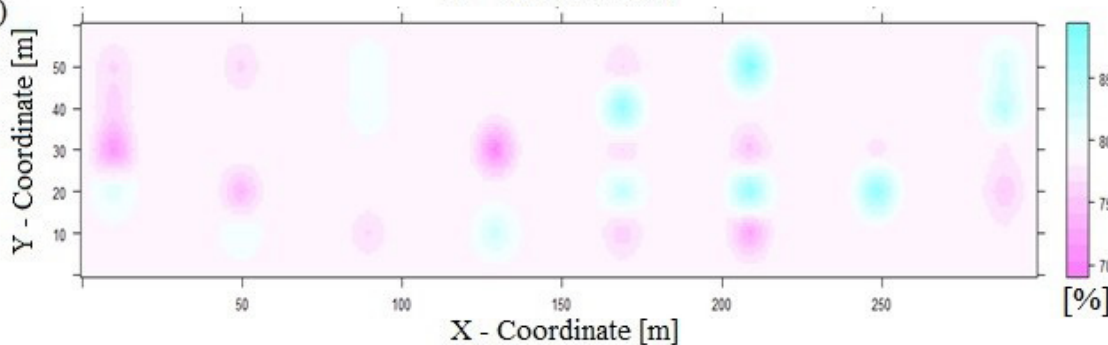

D)

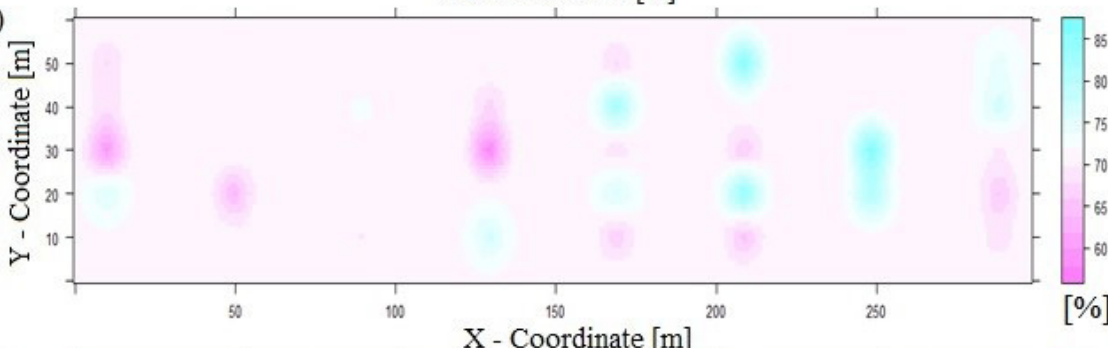

E)

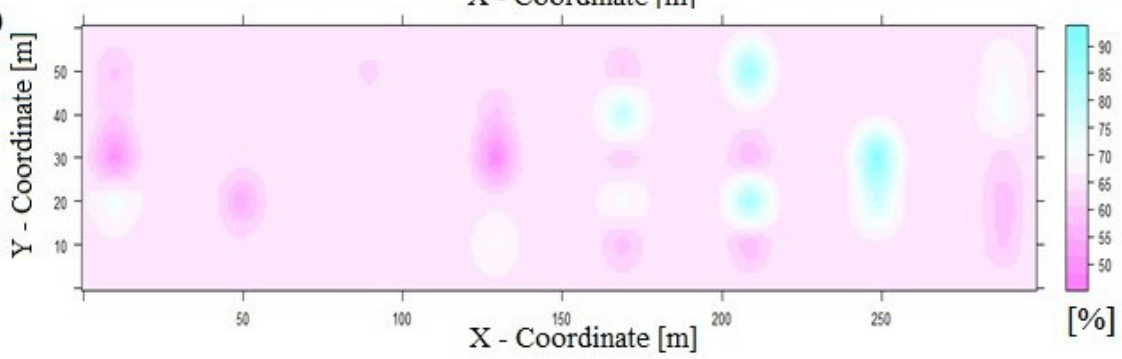

Figure 5. Spatial prediction of relative humidity, A) group 1, B) group 2, C) group 3, D) group 4 and C) group 5.

\section{Vapour pressure deficit}

The graphs for the VPD estimates at the non-sampled points present a heterogeneous spatial trend. This is since VPD is strongly related to relative humidity and air temperature inside the greenhouse and therefore its behavior will be like these variables (Figure 6). It was found that there is an incremental behavior of the vapor pressure deficit values as the radiation values increase. The mean values for the 5 data sets were $0.03,0.19,0.43,0.75$ and $0.81 \mathrm{kPa}$, respectively. On the other hand, during the night hours a situation was estimated in which the difference between the maximum and minimum points of VPD was $0.11 \mathrm{kPa}$ while for the highest level of radiation the same difference was $1.5 \mathrm{kPa}$. 
A)

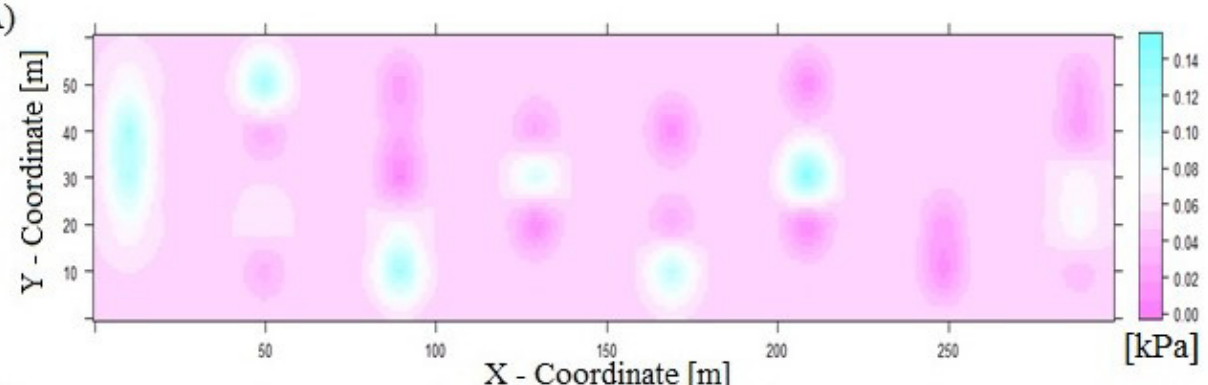

B)

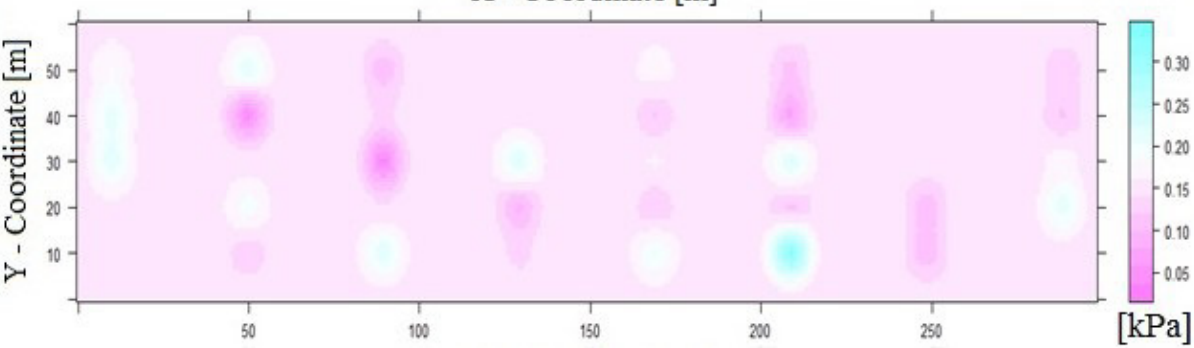

C)

$\mathrm{X}$ - Coordinate $[\mathrm{m}]$

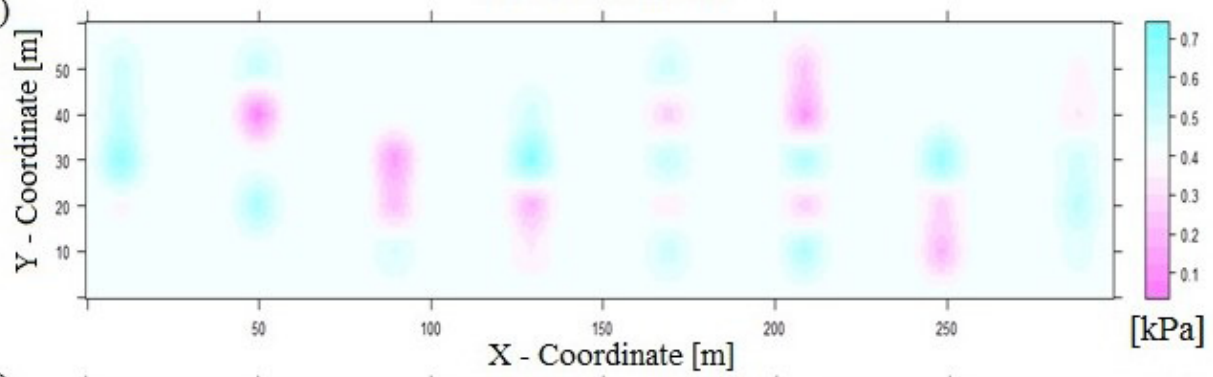

D)

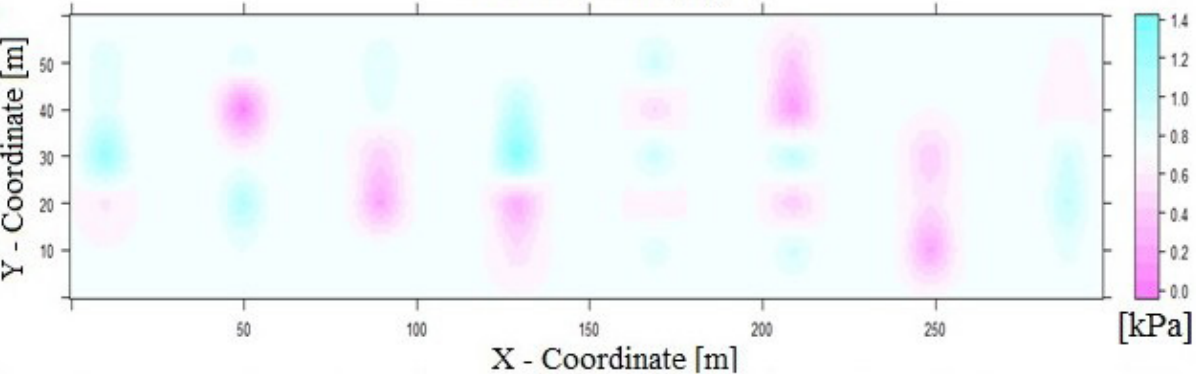

E)

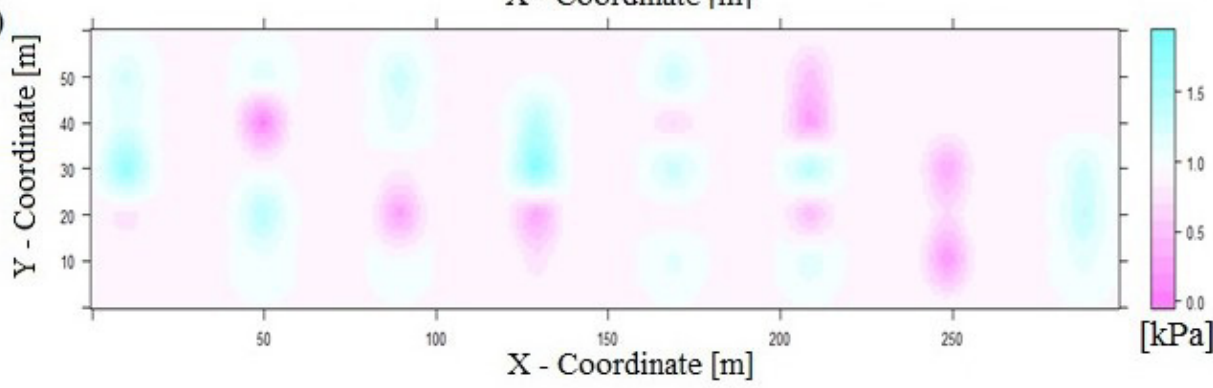

Figure 6. Spatial prediction of the vapour pressure deficit A) group 1, B) group 2, C) group 3, D) group 4 and C) group 5.

These results allow us to suggest that for this type of greenhouse the entrepreneurs of the Colombian ornamental sector should focus their efforts on finding strategies to optimize the microclimatic conditions for both the day and night periods. Therefore, for the day period it is proposed to look for a feasible technical alternative that makes it possible to increase the ventilation surface of the greenhouse until it approaches the recommended values for naturally ventilated structures. This can be achieved by increasing the fixed roof ventilation or by using roll- 
up ventilation (Villagran and Bojaca, 2019c). Also for the conditions of the night period can be sought passive climate strategies through heat accumulators or the use of thermal screens to improve the capacity of heat retention inside the greenhouse and increases in internal temperature between 2 and $4{ }^{\circ} \mathrm{C}$ (Bazgaou et al., 2020, 2018; Gourdo et al., 2019: Villagran and Bojaca, 2019d).

\section{Conclusions}

In this research it was determined that the microclimatic conditions inside a special greenhouse used for carnation production in Colombia are not the most adequate, additionally it was found that there are strong spatial variations in temperature, relative humidity and VPD for both day and night, these factors affect the uniformity and quality of carnation production. Therefore, it is recommended that entrepreneurs in the ornamental sector of the country focus their efforts on seeking and implementing sustainable climate strategies in order to maintain the production and quality demands required in international markets.

\section{Author contribution}

E.A.V. ${ }^{0000-0003-1860-5932}$ : idea creation, experimental monitoring, data analysis and collection, data analysis, preparation of the manuscript. C.R.B. ${ }^{0000-0003-0230-326 x}$ : installation of the experiment, preparation of the manuscript and analysis of results.

\section{Acknowledgements}

The present study was funded by the Servicio Nacional de Aprendizaje (SENA), la Asociación Colombiana de Exportadores de Flores (Asocolflores) y al Centro de Innovación de la Floricultura Colombiana (Ceniflores) through the project "Generación de una herramienta de diseño u optimización de ventilación natural de los invernaderos dedicados a la producción de flores de corte en cuatro subregiones de la Sabana de Bogotá, mediante el uso de herramientas de simulación basadas en la técnica Dinámica de Fluidos Computacional (CFD)".

\section{References}

ABELIOTIS, K.; BARLA, S.A.; DETSIS, V.; MALINDRETOS, G. Life cycle assessment of carnation production in Greece. Journal of Cleaner Production, v.112, p.32-38. 2016. DOI: https://doi. org/10.1016/j.jclepro.2015.06.018.

ADEOLA, O.; MERU, A.K.; KINOTI, M.W. Kenya's Blooming Flower Industry: Enhancing Global Competitiveness. In: ADELEYE, I.; ESPOSITO, M. Africa's Competitiveness in the Global Economy. Switzerland: Springer Nature, 2018. p. 331-349.
AHMADIAN, M.; BABAEI, A.; SHOKRI, S.; HESSAMI, S. Micropropagation of carnation (Dianthus caryophyllus L.) in liquid medium by temporary immersion bioreactor in comparison with solid culture. Journal of Genetic Engineering and Biotechnology, v.15, n.2, p.309-315, 2017. DOI: https://doi.org/10.1016/j.jgeb.2017.07.005.

AL-MA'ATHEDI, A.F.; ABBAS, A.J.; AL-ABDALY, H.M. Effect of growth regulators on improving productivity and quality of carnation (Dianthus caryophyllus L.) flowers with economic study. Annals of Agricultural Sciences, v.63, n.1, p.109-114, 2018. DOI: https://doi. org/10.1016/j.aoas.2018.04.005.

BAEZA, E.J.; PÉREZ-PARRA, J.J.; MONTERO, J.I.; BAILEY, B.J.; LÓPEZ, J.C.; GÁZQUEZ, J.C. Analysis of the role of sidewall vents on buoyancy-driven natural ventilationin parral-type greenhouses with and withoutinsect screens using computational fluid dynamics. Biosystems engineering, v.104, n.1, p.86-96, 2009. DOI: https://doi. org/10.1016/J.BIOSYSTEMSENG.2009.04.008.

BALENDONCK, J.; SAPOUNAS, A.A.; KEMPKES, F.; VAN OS, E.A., SCHOOR, R.; VAN TUIJL, B.A.J.; KEIZER, L.C.P. Using a wireless sensor network to determine climate heterogeneity of a greenhouse environment. Acta horticulturae, v.1037, p.539-546, 2014. DOI: https://doi.org/10.17660/ActaHortic.2014.1037.67.

BAZGAOU, A.; FATNASSI, H.; BOUHARROUD, R.; ELAME, F.; EZZAERI, K.; GOURDO, L.; AHAROUNE, A. Performance assessment of combining rock-bed thermal energy storage and water filled passive solar sleeves for heating Canarian greenhouse. Solar Energy, v.198, p.8-24, 2020. DOI: https://doi.org/10.1016/j.solener.2020.01.041.

BAZGAOU, A.; FATNASSI, H.; BOUHROUD, R., GOURDO, L., EZZAERI, K., TISKATINE, R.; BOUIRDEN, L. An experimental study on the effect of a rock-bed heating system on the microclimate and the crop development under canarian greenhouse. Solar Energy, v.176, p.42-50, 2018. DOI: https://doi. org/10.1016/j.solener.2018.10.027.

BOJACÁ, C.R.; GIL, R.; COOMAN, A. Use of geostatistical and crop growth modelling to assess the variability of greenhouse tomato yield caused by spatial temperature variations. Computers and electronics in agriculture, v.65, n.2, p.219-227. 2009a. DOI: https://doi: 10.1016/j.compag.2008.10.001.

BOJACÁ, C.R.; GIL, R.; GÓMEZ, S.; COOMAN, A.; SCHREVENS, E. Analysis of greenhouse air temperature distribution using geostatistical methods. Transactions of the ASABE, v.52, n.3, p.957-968, 2009b. DOI: https://doi: $10.13031 / 2013.27393$. 
BOSHELL, J. Manejo del riesgo climático en la floricultura colombiana. v.1. Bogota: Ceniflores, 2009. $97 \mathrm{p}$.

BOXRIKER, M.; BOEHM, R.; KREZDORN, N.; ROTTER, B.; PIEPHO, H.P. Comparative transcriptome analysis of vase life and carnation type in Dianthus caryophyllus L. Scientia Horticulturae, v.217, p.61-72. 2017a. DOI: https://doi: 10.1016/ j.scienta.2017.01.015

BOXRIKER, M.; BOEHM, R.; MÖHRING, J.; PIEPHO, H.P. Efficient statistical design in two-phase experiments on vase life in carnations (Dianthus caryophyllus L.). Postharvest Biology and Technology, v.128, p.161-168, 2017b. DOI: https://doi.org/10.1016/j. postharvbio.2016.12.003

CAMBARDELLA, C.A.; MOORMAN, T.B.; PARKIN, T.B., KARLEN, D.L.; NOVAK, J.M.; TURCO, R.F.; KONOPKA, A.E. Field-scale variability of soil properties in central Iowa soils. Soil science society of America journal, v.58, n.5, p.1501-1511, 1994.

CORRELL, M.J.; WEATHERS, P.J. Effects of light, $\mathrm{CO}_{2}$ and humidity on carnation growth, hyperhydration and cuticular wax development in a mist reactor. In Vitro Cellular \& Developmental Biology-Plant, v.37, n.3, p.405-413, 2001. DOI: https://doi.org/10.1007/s11627001-0071-5

CRESSIE, N. Statistics for spatial data. Terra Nova, v.4, n.5, p.613-617, 1992. DOI: https://doi: 10.1111/j.13653121.1992.tb00605.x

DIANO, M.; VALENTINI, M.; SAMELE, P.; DI GESU, I. Exposure to hot environments of horticultural greenhouses workers of the center of Calabria: evaluative comparison methods. Italian Journal of Occupational and Environmental Hygiene, v.7, n.2, p. 58-65, 2016. DOI: https://doi.org/10.36125/ijoehy.v7i2.144

FATNASSI, H.; PIZZOL, J.; SENOUSSI, R.; BIONDI, A.; DESNEUX, N.; PONCET, C.; BOULARD, T. Within-Crop air temperature and humidity outcomes on spatio-temporal distribution of the key rose pest Frankliniella occidentalis. PloS one, v.10, n.5, e0126655, 2015. https://doi: 10.1371/ journal.pone. 0126655

FERENTINOS, K.P.; KATSOULAS, N.; TZOUNIS, A.; BARTZANAS, T.; KITTAS, C. Wireless sensor networks for greenhouse climate and plant condition assessment. Biosystems Engineering, v.153, p.70-81, 2017. DOI: https://doi: 10.1016/j.biosystemseng.2016.11.005
GARCÍA-RUIZ, R.A.; LÓPEZ-MARTÍNEZ, J.; BLANCO-CLARACO, J.L.; PÉREZ-ALONSO, J.; CALLEJÓN-FERRE, Á. J. On air temperature distribution and ISO 7726-defined heterogeneity inside a typical greenhouse in Almería. Computers and Electronics in Agriculture, v.151, p.264-275, 2018. DOI: https://doi: 10.1016/j.compag.2018.06.001

GONZÁlEZ, C.V.; CORTÉS, V.G.; CAICONTE, P.C.; RODRÍGUEZ, M.B.; FUENTES, J.F.; FIGUEROA, Á.V.; CRUZ, C.C. Evaluación de desempeño de un invernadero ubicado en el desierto de Atacama, Chile. Interciencia, v.44, n.7, p.386-393, 2019.

GOURDO, L.; FATNASSI, H.; BOUHARROUD, R.; EZZAERI, K.; BAZGAOU, A.; WIFAYA, A.; BOUIRDEN, L. Heating canarian greenhouse with a passive solar water-sleeve system: Effect on microclimate and tomato crop yield. Solar Energy, v.188, p.1349-1359, 2019. DOI: https://doi.org/10.1016/j.solener.2019.07.004

HUANG, Y.; JIN, Y.; ZHANG, K.; YANG, S. A method to measure humidity based on dry-bulb and wet-bulb temperatures. Research Journal of Applied Sciences, Engineering and Technology, v.16, n.16, p.2984-2987, 2013.

ISAAKS, E.H.; SRIVASTAVA, R.M. An introduction to applied geostatistics. v.1. New York: Oxford University Press, 1989. 592p.

JUNQUEIRA, A.H.; PEETZ, M.D.S. Sustainability in Brazilian floriculture: introductory notes to a systemic approach. Ornamental Horticulture, v.24, n.2, p.155162, 2018. DOI: https://doi.org/10.14295/oh.v24i2.1253

KNAPP, G. Mountain agriculture for global markets: The case of greenhouse floriculture in Ecuador. Annals of the American Association of Geographers, v.107, n.2, p.511519, 2017. DOI: https://doi.org/10.1080/24694452.2016.1 203282

KONOPACKI, P.J.; TREDER, W.; KLAMKOWSKI, K. Comparison of vapour pressure deficit patterns during cucumber cultivation in a traditional high PE tunnel greenhouse and a tunnel greenhouse equipped with a heat accumulator. Spanish Journal of Agricultural Research, v.16, n.1, p.4, 2018. DOI: https://doi. org/10.5424/sjar/2018161-11484

LIU, J.; ZHANG, Z.; LI, H.; LIN, X.; LIN, S., JOYCE, D.C.; HE, S. Alleviation of effects of exogenous ethylene on cut 'Master'carnation flowers with nanosilver and silver thiosulfate. Postharvest Biology and Technology, v.143, p.86-91, 2018. DOI: https://doi. org/10.1016/j.postharvbio.2018.04.017 
LÓPEZ-CRUZ, I.L.; FITZ-RODRÍGUEZ, E.; SALAZARMORENO, R.; ROJANO-AGUILAR, A.; KACIRA, $M$. Development and analysis of dynamical mathematical models of greenhouse climate: A review. European Journal of Horticultural Science, v.83, n.5, p.269-279, 2018. DOI: https://doi.org/10.17660/eJHS.2018/83.5.1

MA, D.; CARPENTER, N., MAKI, H.; REHMAN, T.U.; TUINSTRA, M.R.; JIN, J. Greenhouse environment modeling and simulation for microclimate control. Computers and Electronics in Agriculture, v. 162, p.134-142, 2019b. DOI: https://doi.org/10.1016/j. compag.2019.04.013.

MA, D.; CARPENTER, N.; AMATYA, S.; MAKI, H.; WANG, L.; ZHANG, L.; JIN, J. Removal of greenhouse microclimate heterogeneity with conveyor system for indoor phenotyping. Computers and Electronics in Agriculture, v.166, p.104979, 2019a. DOI: https://doi. org/10.1016/j.compag.2019.104979.

MÁRQUEZ, M.P Clavel Dianthus caryophyllus. v1. Bogotá: Ed Hortitecnia Ltda., 2000.181p.

NASSAR, P.P.M.; RIBEIRO, M.G. Considerations for cholinesterase biomonitoring in flower and ornamental plant greenhouse workers. Science of The Total Environment, v.711, p.135228, 2019. DOI: https://doi.org/10.1016/j. scitotenv.2019.135228

NEIRA， D.P.; MONTIEL， M.S.; CABEZA， M.D.; REIGADA,A. Energy use and carbon footprint of the tomato production in heated multi-tunnel greenhouses in Almeria within an exporting agri-food system context. Science of The Total Environment, v.628, p.1627-1636, 2018. DOI: https://doi.org/10.1016/j.scitotenv.2018.02.127

NEWMAN, S. Efectos del clima en la fisiología de la floración. Clima fisiología y producción de cultivos bajo invernadero. v.1. Bogotá: Rebecca Lee, 2009. 34p.

NEWMAN, S.E. Floriculture. In: NRIAGU, J. (ed.). Encyclopedia of Environmental Health $\left(2^{\text {nd }}\right.$ Ed.). Oxford: Elsevier, 2019. p. 19-33.

ONOZAKI, T. Dianthus. In: HUYLENBROECK, J.V. Ornamental Crops. v.1. Belgium: Springer, 2018. p.349381.
PAIVA, P.D.O. Horticulture and Ornamental Horticulture. Ornamental Horticulture, v.24, n.1, p.6, 2018. DOI: https://doi.org/10.14295/oh.v24i1.1175

RABBI, B.; CHEN, Z.H.; SETHUVENKATRAMAN, S. Protected cropping in warm climates: a review of humidity control and cooling methods. Energies, v.12, n.14, p.2737, 2019. DOI: https://doi.org/10.3390/en12142737

RODRÍGUEZ, R.G, JUNCO, C.A. An approach to characterising the competitiveness of the industrial and floricultural production sectors of the Municipality of Madrid Cundinamarca, Colombia. Suma de Negocios, v.7, n.16, p.82-93, 2016. DOI: https://doi.org/10.1016/j. sumneg.2016.02.006

SABERIAN, A.; SAJADIYE, S.M. The effect of dynamic solar heat load on the greenhouse microclimate using CFD simulation. Renewable Energy, v.138, p.722-737, 2019. DOI: https://doi: 10.1016/j.renene.2019.01.108

SINGH, A.; SHARMA, B.P.; DILTA, B.S.; GUPTA, Y.C., LAISHRAM, N.; BAWEJA, H.S. Economic analysis of Carnation cv.'Master'cut flower production as influenced by fertilizer schedules under naturally ventilated polyhouse. Bangladesh Journal of Botany, v.45, p.25-31, 2016.

VILLAGRÁN MUNAR, E.A.; BOJACÁ ALDANA, C.R.; ROJAS BAHAMON, N.A Determinacion del comportamiento térmico de un invernadero espacial colombiano mediante dinámica de fluidos computacional. Revista U.D.C.A Actualidad y Divulgacion Cientifica. v.21, p.415-426, 2018. DOI: https://doi.org/https://doi. org/10.31910/rudca.v21.n2.2018.10700

VILLAGRÁN, E., BOJACÁ, C. CFD simulation of the increase of the roof ventilation area in a traditional Colombian greenhouse: effect on air flow patterns and thermal behavior. International Journal of Heat and Technology, v.37, n.3, p.881-892, 2019c. DOI: https://doi. org/10.18280/ijht.370326

VILLAGRÁN, E.A., BOJACÁ, C.R. Effects of surrounding objects on the thermal performance of passively ventilated greenhouses. Journal of Agricultural Engineering, v.50, n.1, p.20-27, 2019b. DOI: https://doi.org/10.4081/ jae.2019.856 
VILLAGRÁN, E.A.; BOJACÁ, C.R. Numerical evaluation of passive strategies for nocturnal climate optimization in a greenhouse designed for rose production (Rosa spp.). Ornamental Horticulture, v.25, n.4, p.351-364, 2019d. DOI: https://doi: 10.1590/2447-536X.V25I4.2087

VILLAGRÁN, E.A.; BOJACÁ, C.R. Study of natural ventilation in a Gothic multi-tunnel greenhouse designed to produce rose (Rosa spp.) in the high-Andean tropic. Ornamental Horticulture, v.25, p.133-143, 2019a. DOI: https://doi.org/https://doi.org/10.14295/oh.v25i2.2013.

VILLAGRÁN, E.A.; ROMERO, E.J.B.; BOJACÁ, C.R. Transient CFD analysis of the natural ventilation of three types of greenhouses used for agricultural production in a tropical mountain climate. Biosystems Engineering, v.188, p.288-304, 2019. DOI: https://doi: 10.1016/j. biosystemseng.2019.10.026
VILLAGRÁN-MUNAR， E.A.; BOJACÁ-ALDANA, C.R. Determinación del comportamiento térmico de un invernadero colgante colombiano aplicando simulación CFD. Revista Ciencias Técnicas Agropecuarias, v.28, n.3, 2019.

YAGI, M.; SHIRASAWA, K.; HIRAKAWA, H.; ISOBE, S.; MATSUNO, J.; UNO, Y.; YAMAGUCHI, H. QTL analysis for flowering time in carnation (Dianthus caryophyllus L.). Scientia Horticulturae, v.262, p.109053. 2020. DOI: https://doi.org/10.1016/j.scienta.2019.109053 